\title{
Modified pubovaginal sling technique in the surgical management of female stress urinary incontinence
}

\section{Técnica modificada do sling pubovaginal no tratamento cirúrgico da incontinência urinária de esforço feminina}

\author{
Armando Brites Frade ${ }^{1}$; Camila luz Frade ${ }^{2}$; Thäis Gentul Leite ${ }^{1}$; Thalita Russo Domenich ${ }^{1}$; Antonio Pedro Flores Auge ${ }^{1}$
}

A B S T R A C T

\begin{abstract}
Objective: To assess the application of aponeurotic sling by a modified technique with direct visualization of needles in patients with stress urinary incontinence. Methods: we applied the Kings Health Questionnaire (KHQ) for quality of life, gynecological examination, urinalysis I and urine culture approximately seven days prior to the urodynamic study (UDS) and the one-hour PAD test in patients undergoing making aponeurotic sling with its passing through the retropubic route with direct visualization of the needle, PAD test and King's Helth Questionnaire before and after surgery. Results: The mean age was 50.6 years, BMI of 28 and Leak Pressure (LP) $58,5 \mathrm{~cm} \mathrm{H} \mathrm{H}_{2}$; $89 \%$ were Caucasian. Forty-six of them were monitored for three and six months, 43 for 12 months. The objective cure rate at 12 months postoperatively was approximately $93.5 \%$. In evaluating quality of life, we observed a significant improvement in 12 months postoperatively compared with the preoperative period. There was no no urethral/bladder injury. As adverse results, we had one persistent urinary retention $(2.3 \%)$, who was submitted to urethrolysis, currently without incontinence. Conclusion: The proposed procedure is safe as for the risk of bladder or urethral injuries, promoting significant improvement in quality of life and objective cure.
\end{abstract}

Key words: Urinary Incontinence/Surgery; Suburethral Slings; Urologic Surgical Procedures/Methods.

\section{INTRODUCTION}

$\mathrm{T}^{\mathrm{s}}$ he operation using a pubovaginal slings for the correction of stress urinary incontinence (SUI) was described in 1907 by Von Giordano'. In 1910, Goebell² describes a technique that releases the pyramidal muscles involving the proximal urethra. Price, in 1933, first described the sling. Aldridge, in 1942, innovated and combined the Goebell-FrangenheimStoeckel operation with the Price ${ }^{2}$ one by removing two aponeurotic bands from the rectus abdominis muscle, keeping the median portion intact, rotating the free lateral edges down through the rectus abdominis muscles to the urethra, where they were joined.

For a long time the techniques of pubovaginal sling (PVS) fell into disuse due to technical difficulties and the high incidence of complications. In 1978, the aponeurotic sling operation was reintroduced ${ }^{3}$ with good results.

From the 1990 Integral Theory ${ }^{4}$, a new surgical technique was developed, using a synthetic polypropylene sling positioned in the middle urethra, through the passage of needles for fixation in the retropubic position and without tension, known as tension-free vaginal tape (TVT). Currently, this operation with synthetic sling is considered the gold standard in the correction of SUI5,6. However, it is not without its adversities, such as extrusion, erosion, infection, and vessels, bowel or bladder perforations ${ }^{7-11}$.

Taking into account all these factors and the clarification that it is necessary to the patient, an important part in the treatment choice, we decided to evaluate the implementation of an aponeurotic sling through a modified technique with direct visualization of the needles in patients with stress urinary incontinence.

\section{METHODS}

We conducted a prospective cohort study on placement of aponeurotic sling under direct visualization, a prospective analysis of cure rate and quality of life in women with stress urinary incontinence, involving 64 women with clinical and urodynamic diagnosis of SUI, from the Urogynecology and Vaginal Surgery Clinic, Department of Obstetrics and Gynecology (DOGI) of the Hospital Central da Irmandade da Santa Casa de Misericórdia de São Paulo (ISCMCSP) and the Complexo Hospitalar Padre Bento de Guarulhos, from August 2008 to August 2013. The urodynamic exams were carried out with a Uranus®

1. Departamento de Obstetrícia e Ginecologia (DOGI) da Faculdade de Ciências Médicas da Santa Casa de São Paulo, Brasil; 2. Programa de PósGraduação em Tocoginecologia da Faculdade de Ciências Médicas da Santa Casa de São Paulo, Brasil. 
equipment of Alacer and Urosystem ds $2600 \AA$ of Viotti and associates.

The study was approved by the Ethics in Medical Research of the Faculty of Medical Sciences Research Committee of the Santa Casa de São Paulo, under protocol number 334/08.

The study included patients who had urinary leakage at clinical examination and urodynamic study. As exclusion criteria, there were: pure urgency urinary incontinence, urinary tract infection, chronic decompensated diseases, severe genital dystopias (prolapse grade III or IV by the POP-Q), neurogenic bladder and patients who refused to participate in the study.

Patients were submitted to anamnesis, application of the Kings Health Questionnaire (KHQ) on quality of life ${ }^{12}$ and gynecological examination. We ordered urinalysis I and urine culture seven days prior to the urodynamic study (UDS) and one-hour PAD test ${ }^{13}$. The PAD test showing small leakages was regarded as an objective cure criterion, and the 12 months $K H Q$, a subjective one. We considered urinary retention the need for intermittent vesical catheter after 30 days.

All participants were asked to return in three, six and 12 months after surgery to control and re-evaluation of PAD test and KHQ. To assess urinary leakage through the PAD test, we performed analysis of variance with repeated measures (ANOVA).

\section{Surgical technique}

We initiated with a transverse abdominal incision approximately two centimeters above the pubic symphysis, exposing the aponeurosis of the rectus abdominis, and resecting it in a diamond-shaped sling with about $10 \mathrm{~cm}$ in longitudinal diameter and $1.5 \mathrm{~cm}$ in transverse diameter at its central portion. We then held a suture with 0 mononylon in the edges of the aponeurosis and placed the sling in saline to keep it hydrated.

We exposed the retropubic space by blunt dissection till the identification of the bladder neck. We then followed to the vaginal time, with an incision in the anterior vaginal wall mucosa $1.5 \mathrm{~cm}$ from the external urethral meatus, at the level of the middle urethra, of approximately $2.5 \mathrm{~cm}$, in the midline. The dissection was carried out bilaterally with a curved Metzenbaun scissor toward the patient's ipsilateral shoulder and the aspect of the collected urine was checked.
The first assistant positioned and kept his index and middle fingers in the retropubic space, leaving the Foley catheter at the level of the middle urethra, after traction of the catheter and identification of the balloon (bladder neck). The classic needle for passage of the synthetic retropubic slings with attached suture was passed vaginally toward the first assistant's finger lateral edge, transfixing the endopelvic fascia up to the aponeurosis of the rectus abdominis muscle. We repeated the passage on the other side.

After each passage of the needle the suture was released from the needle and the urine aspect checked. Should it present with hematuria, cystoscopy was performed. The sling adjustment was made without tension, leaving the space of a hysterometer cable between the urethra and the sling. The ends of the nylon stitches were attached to the aponeurosis by transfixation without traction.

\section{RESULTS}

Sixty-four patients underwent the proposed operation, 46 meeting the minimum following criteria of three and six months and 43, twelve months, comprising the sample. Most were white (89\%), with mean and median of 52.3 and 53 years for age,BMl 28 and $29 \mathrm{Kg} / \mathrm{m}^{2}$, and effort loss pressure (ELP) of 66.2 and $58 \mathrm{~cm} \mathrm{H} 2 \mathrm{O}$, respectively.

We evaluated the absolute (n) and relative (\%) frequencies of the PAD test results(Table 1). We observed regression in urine loss. Over time, patients evolved to better states: at six months, $89 \%$ showed no loss and $11 \%$ had low losses, while at end of 12 months, these figures were $80.4 \%$ and $13.1 \%$, respectively, with loss of the information of some patients who did not return to the visits (6.5\%).

There was a marked fall in urinary loss in grams from the preoperative time up to three months, and a smooth reduction from three to 12 months (Figure 1).

We found a significant difference $(p<0.001)$ in the overall assessment of urine losses in the postoperative period. The intervals pre- $3 m$, pre- $6 m$, pre- $12 m$ and $3 m-6 m$ showed significant differences, but we did not observe significant differences in the intervals $3 m-12 m$ and $6 m-12 m$, despite improvements in the reported complaints (Table 2).

Table 1 - $\quad$ Pad test- Absolute (n) and relative (\%) frequencies.

\begin{tabular}{lccccc}
\hline Time & $\begin{array}{c}\text { Negligible } \\
(\mathbf{0}-\mathbf{1 g})\end{array}$ & $\begin{array}{c}\text { Mild } \\
(\mathbf{1 . 1}-\mathbf{9 . 9})\end{array}$ & $\begin{array}{c}\text { Moderate } \\
(\mathbf{1 0}-\mathbf{4 9 . 9 g )}\end{array}$ & $\begin{array}{c}\text { Severe } \\
\text { (Above de 50g) }\end{array}$ & $\begin{array}{c}\text { Without } \\
\text { information }\end{array}$ \\
\hline Preoperative & $0(0.0)$ & $17(36.9)$ & $24(52.2)$ & $5(10.9)$ & $0(0.0)$ \\
3 Months & $34(73.9)$ & $11(23.9)$ & $1(2.1)$ & $0(0.0)$ & $0(0.0)$ \\
6 Months & $41(89.1)$ & $5(10.9)$ & $0(0.0)$ & $0(0.0)$ & $0(0.0)$ \\
12 Months & $37(80.4)$ & $6(13.1)$ & $0(0.0)$ & $0(0.0)$ & $3(6.5)$ \\
\hline
\end{tabular}


For evaluating the impact of stress urinary incontinence on quality of life, we calculated averages in the various fields, all displaying identical plots. We present only the impact of urinary incontinence (Figure 2). We found significant differences when comparing the preoperative period with the averages of the several domains (Table 3 ).

\section{DISCUSSION}

Female SUI is a disorder that causes negative impact on quality of life of women, can not and should not be considered natural, since it causes emotional, personal and social difficulties, as well as biological alterations, greatly affecting their self-esteem.

Of the 64 patients submitted to the proposed treatment in our study, none had urethral or bladder injury as adverse outcome due to the passage of the needles.

The Pad test showed $93.5 \%$ cure in 12 months. This value is consistent with the literature ones, $83 \%$ to $94 \%{ }^{8,14-16}$.

Table 2 - PAD test comparison for the different intervals.

\begin{tabular}{lc}
\hline $\begin{array}{l}\text { Pad test } \\
\text { General }\end{array}$ & $\begin{array}{r}p \text {-value } \\
<0,001\end{array}$ \\
\hline Multiple comparisons & \\
Pre $-3 m$ & $<0.001$ \\
Pre $-6 m$ & $<0.001$ \\
Pre $-12 m$ & $<0.001$ \\
$3 m-6 m$ & 0.007 \\
$3 m-12 m$ & 0.098 \\
$6 m-12 m$ & 0.068 \\
\hline
\end{tabular}

General significance level $=5 \%$

Level of significance of each comparison $=0.05 / 6=0.008$
Urinary retention is a frequent adverse outcome in the postoperative period. In this study, we had three $(6.9 \%)$ patients with urinary retention in the immediate postoperative period and one with persistent retention $(2.3 \%)$, which is consistent with the literature $(19.7 \%)^{7,8,17-}$ ${ }^{23}$. These patients were referred for pelvic floor

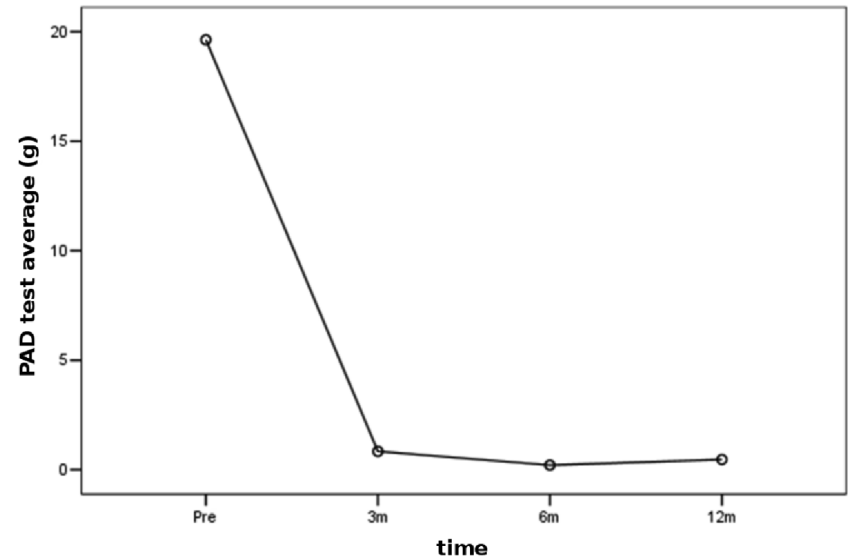

Figure 1 - Profile of averages - PAD test $(g)$

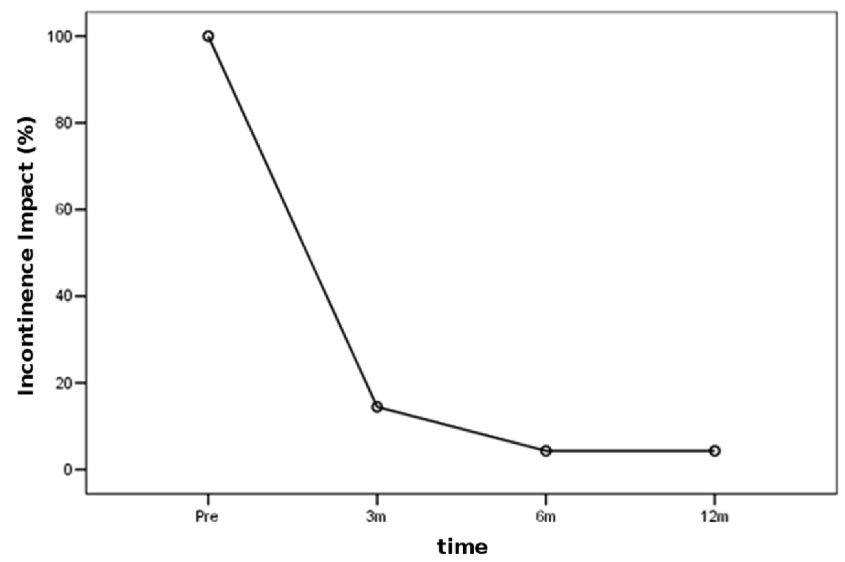

Figure 2 - Profile of averages - Impact of incontinence.

Table 3 - $\quad$ Analysis of variance with summary measures (General).

\begin{tabular}{lccccccc}
\hline Variable & Anova & \multicolumn{5}{c}{ Multiple comparisons } \\
& M R & 3m-pre & 6m-pre & $12 \mathrm{~m}$-pre & $6 \mathrm{~m}-3 \mathrm{~m}$ & $12 \mathrm{~m}-3 \mathrm{~m}$ & $12 \mathrm{~m}-6 \mathrm{~m}$ \\
\hline Pad test & $<0.001$ & $<0.001$ & $<0.001$ & $<0.001$ & 0.007 & 0.098 & 0.068 \\
General Perception & $<0.001$ & $<0.001$ & $<0.001$ & $<0.001$ & 0.008 & 0.008 & 1.000 \\
Impact of incontinence & $<0.001$ & $<0.001$ & $<0.001$ & $<0.001$ & 0.020 & 0.020 & 1.000 \\
Limitation of daily activities & $<0.001$ & $<0.001$ & $<0.001$ & $<0.001$ & 0.070 & 0.070 & 1.000 \\
Physical Limitation & $<0.001$ & $<0.001$ & $<0.001$ & $<0.001$ & 0.014 & 0.014 & 1.000 \\
Social Limatação & $<0.001$ & $<0.001$ & $<0.001$ & $<0.001$ & 0.016 & 0.011 & 0.317 \\
Personal Relationships & $<0.001$ & $<0.001$ & $<0.001$ & $<0.001$ & 0.024 & 0.024 & 1.000 \\
Emotions & $<0.001$ & $<0.001$ & $<0.001$ & $<0.001$ & 0.006 & 0.006 & 1.000 \\
Sleep and Mood & $<0.001$ & $<0.001$ & $<0.001$ & $<0.001$ & 0.034 & 0.034 & 1.000 \\
Measures of Severity & $<0.001$ & $<0.001$ & $<0.001$ & $<0.001$ & 0.027 & 0.027 & 0.317 \\
\hline
\end{tabular}

Significance level $=5 \%$ 
physiotherapy. Two of them had resolution of the condition and voiding study compatible with normality. One patient still had urinary retention requiring intermittent catheterization, the voiding study revealing urethral opening pressure of $45 \mathrm{cmH} 2 \mathrm{O}$. The patient underwent urethrolysis, with good evolution, being continent and without complaints.

The rate of bladder / urethral injury reported, according to several authors, ranges from zero to $13.8 \%{ }^{19-}$ $21,24-27$. In our series, we had no adverse outcomes in this regard.

When separately analyzing each of the domains, comparing the preoperative period with three, six and 12 months postoperatively, we noted that there was a statistically significant difference.

We believe that, from the points of view of surgical results and improving the life of our patients, our technique proved to be efficient. We believe there is room for its use in SUI relapsing from conventional techniques ${ }^{21,23}$ and in cases of rejection of synthetic materials or selected patients, considering that the ideal treatment for female $\mathrm{SUl}$ is yet to $\mathrm{Come}^{28}$.

In conclusion, the retropubic placement of aponeurotic sling with direct visualization proved to be safe as for the risk of bladder or urethral injuries, with objective cure rate and improved quality of life.

\section{R E S U M O}

Objetivo: avaliar a aplicação de faixa aponeurótica por técnica modificada com visibilização direta das agulhas em pacientes com incontinência urinária de esforço. Métodos: foi aplicado o questionário Kings Health Questionaire (KHQ) de qualidade de vida, exame ginecológico, exame de urina I e urocultura aproximadamente sete dias antes da realização do estudo urodinâmico (EUD) e PAD test de uma hora submetidas à confecção de faixa aponeurótica com passagem de faixa pela via retropúbica, com agulha sob visibilização direta, PAD test e King's Helth Questionaire, no pré e pós operatórios. Resultados: a média de idade foi 50,6 anos, 89\% da cor branca, IMC de 28 e PPE de 58,5cm de $\mathrm{H}_{2} \mathrm{O}$. Quarenta e seis delas tiveram acompanhamento de três e seis meses, 43 de 12 meses. A taxa de cura objetiva, em 12 meses de pós-operatório foi aproximadamente 93,5\%. Ao avaliarmos a qualidade de vida das pacientes, observamos a melhora significante em 12 meses de pós-operatório, quando comparada ao pré-operatório. Não foi observada nenhuma lesão uretral/vesical. Como resultados adversos tivemos uma retenção urinária persistente $(2,3 \%)$, sendo submetida à uretrolíse, estando atualmente sem perda. Conclusão: a operação proposta é segura quanto ao risco de lesões vesicais ou uretrais, promovendo melhora acentuada na qualidade de vida e cura objetiva.

Descritores: Incontinência urinária/cirurgia. Slings suburetrais. Procedimentos cirúrgicos urológicos/métodos.

\section{REFERENCES}

1. Giordano V. Vingtieme Congress Français de Chirurgie 1907; p.506.

2. Ridley JH. A operação de Goebell-Stoeckel. In: Mattingly RF, Thompson JD. TeLinde Ginecologia operatória. Tradução de J. Israel Lemos e André Luis Melgaço. $6^{\text {a }}$ ed. Rio de Janeiro: Guanabara Koogan;1988. p.583-96.

3. Mcguire EJ, Lytton B. Pubovaginal sling procedure for stress incontinence. J Urol. 1978;119(1):82-4.

4. Petros PE, Ulmsten UI. An integral theory of female urinary incontinence. Acta Obstet Gynecol Scand Suppl. 1990;153:7-31.

5. Nilsson CG, Falconer C, Rezapour M. Seven-year follow-up of the tension-free vaginal tape procedure for the treatment of urinary incontinence. Obstet Gynecol. 2004;104(6):1259-62.

6. Novara G, Ficarra V, Boscolo-Berto R, Secco S, Cavalleri S, Artibani $W$. Tension-free midurethral slings in the treatment of female stress urinary incontinence: a systematic review and meta-analysis of randomized controlled trials of effectiveness. Eur Urol. 2007;52(3):663-78.

7. Sergent F, Sebban A, Verspyck E, Sentilhes L, Lemoine JP, Marpeau L. Complications per et post-opératoires du TVT (tension-free vaginal tape). Prog Urol. 2003;13(4):648-55.

8. Winckler JA, Ramos JG, Dalmolin BM, Winckler DC, Doring M Comparative study of polypropylene and aponeurotic slings in the treatment of female urinary incontinence. Int Braz J Urol. 2010;36(3):339-47

9. Sabadell J, Poza JL, Esgueva A, Morales JC, Sánchez-Iglesias JL, Xercavins J. Usefulness of retropubic tape for recurrent stress incontinence after transobturator tape failure. Int Urogynecol J. 2011;22(12):1543-7.

10. Petri E, Ashok K. Comparison of late complications of retropubic and transobturator slings in stress urinary incontinence. Int Urogynecol J. 2012;23(3):321-5.

11. Rajendra M, Han HC, Lee LC, Tseng LA, Wong HF. Retrospective study on tension-free vaginal tape obturator (TVT-O). Int Urogynecol J. 2012;23(3):327-34.

12. Fonseca ESM, Camargo ALM, Castro RA, Sartori MGF, Fonseca MCM, Lima GR, et al. Validação do questionário de qualidade de vida (King's Health Questionaire) em mulheres brasileiras com incontinência urinária. Rev Bras Ginecol Obstet. 2005;27(5):235-42.

13. Albuquerque MT, Micussi BC, Soares EMM, Lemos TMAM, Brito TNS, Silva JB, et al. Correlação entre as queixas de incontinência urinária de esforço e o pad test de uma hora em mulheres na pósmenopausa. Rev Bras Ginecol Obstet. 2011;33(2):70-4.

14. Sharifiaghdas F, Mortazavi N. Tension-free vaginal tape and autologous rectus fascia pubovaginal sling for the treatment of urinary stress incontinence: a medium-term follow-up. Med Princ Pract. 2008;17(3):209-14.

15. Jeon MJ, Jung HJ, Chung SM, Kim SK, Bai SW. Comparison of the treatment outcome of pubovaginal sling, tension-free vaginal tape, and transobturator tape for stress urinary incontinence with intrinsic sphincter deficiency. Am J Obstet Gynecol. 2008;199(1):76.e1-4

16. Tsui KP, Ng SC, Yeh GP, Hsieh PC, Lin LY, Chen GD. Outcomes of autologous fascial slingplasty procedure for treating female urinary incontinence. Int Urogynecol J Pelvic Floor Dysfunct. 2008;19(7):94954. 
17. Abouassaly R, Steinberg JR, Lemieux M, Marois C, Gilchrist LI, Bourque $J \mathrm{~L}$, et al. Complications of tension-free vaginal tape surgery: a multi-institutional review. BJU Int. 2004;94(1):110-3.

18. Latthe PM, Foon R, Toozs-Hobson P. Transobturator and retropubic tape procedures in stress urinary incontinence: a systematic review and meta-analysis of effectiveness and complications. BJOG. 2007;114(5):522-31.

19. Noblett KL, Shen B, Lane FL. Lynx midurethral sling system: a 1year prospective study on efficacy and safety. Int Urogynecol J Pelvic Floor Dysfunct. 2008;19(9);1217-21.

20. Sartori JP, Martins JAM, Castro RA, Sartori MGF, Girão MJBC. Sling de aponeurose e com faixa sintética sem tensão para o tratamento cirúrgico da incontinência urinária de esforço feminina. Rev Bras Ginecol Obstet. 2008;30(3):127-34.

21. Pradhan A, Kearney R. Surgical management of stress urinary incontinence. Obstet, Gynecol Reprod Med. 2010;20(7):207-11.

22. Goldman HB. Urethrolysis. Urol Clin North Am. 2011;38(1):31-7, vi.

23. Welk BK, Herschon $S$. The autologous fascia pubovaginal sling for complicated female stress incontinence. Can Urol Assoc J. 2012;6(1)36-40.

24. Kuuva N, Nilsson CG. A nationwide analysis of complications associated with the tension-free vaginal tape (TVT) procedure. Acta Obstet Gynecol Scand. 2002;81(1):72-7.
25. Lord HE, Taylor JD, Finn JC, Tsokos N, Jeffery JT, Atherton MJ, et al. A randomized controlled equivalence trial of short-term complications and efficacy of tension-free vaginal tape and suprapubic urethral support sling for treating stress incontinence. BJU Int. 2006;98(2):367-76.

26. Roth CC, Winters JC, Woodruff AJ. What's new in slings: an update on midurethral slings. Curr Opin Urol. 2007;17(4):242-7.

27. Tcherniakovsky M, Fernandes CE, Bezerra CA, Del Roy CA, Wroclawski ER. Comparative results of two techniques to treat stress urinary incontinence: synthetic transobturator and aponeurotic slings. Int Urogynecol J Pelvic Floor Dysfunct. 2009;20(8):961-6.

28. Kassardjian ZG. Sling procedures for urinary incontinence in women. BJU Int. 2004;93(5):665-70.

Received at: 05/03/2015

Accepted for publication: 06/05/2015

Conflict of interest: none.

Source of funding: none.

Mailing address:

Armando Brites Frade

E-mail: armandobfrade@gmail.com 